\title{
Aristolochic acid suppresses DNA repair and triggers oxidative DNA damage in human kidney proximal tubular cells
}

\author{
YA-YIN CHEN ${ }^{1,5}$, JING-GUNG CHUNG $^{2}$, HSIU-CHING WU ${ }^{3}$, DA-TIAN BAU ${ }^{1}$, KUEN-YUH WU $^{1,6}$, \\ SHUNG-TE KAO ${ }^{1,5}$, CHIEN-YUN HSIANG ${ }^{4 *}$, TIN-YUN HO ${ }^{*}$ and SU-YIN CHIANG ${ }^{*}$ \\ ${ }^{1}$ School of Chinese Medicine, ${ }^{2}$ Department of Biological Science and Technology, ${ }^{3}$ School of Post-Baccalaureate \\ Chinese Medicine, ${ }^{4}$ Department of Microbiology, China Medical University, Taichung; ${ }^{5}$ Department of Chinese Medicine, \\ China Medical University Hospital, Taichung; ${ }^{6}$ Institute of Occupational Medicine and Industrial Hygiene, \\ College of Public Health, National Taiwan University, Taipei, Taiwan
}

Received March 2, 2010; Accepted April 13, 2010

DOI: 10.3892/or_00000839

\begin{abstract}
Aristolochic acid (AA), derived from plants of the Aristolochia genus, has been proven to be associated with aristolochic acid nephropathy (AAN) and urothelial cancer in AAN patients. In this study, we used toxicogenomic analysis to clarify the molecular mechanism of AA-induced cytotoxicity in normal human kidney proximal tubular (HK-2) cells, the target cells of AA. AA induced cytotoxic effects in a dose-dependent $(10,30,90 \mu \mathrm{M}$ for $24 \mathrm{~h})$ and timedependent manner (30 $\mu \mathrm{M}$ for 1, 3, 6, 12 and $24 \mathrm{~h}$ ). The cells from those experiments were then used for microarray experiments in triplicate. Among the differentially expressed genes analyzed by Limma and Ingenuity Pathway Analysis software, we found that genes in DNA repair processes were the most significantly regulated by all AA treatments. Furthermore, response to DNA damage stimulus, apoptosis, and regulation of cell cycle, were also significantly regulated by AA treatment. Among the differentially expressed genes found in the dose-response and time-course studies that were involved in these biological processes, two up-regulated $(G A D D 45 B, N A I P)$, and six down-regulated genes (TP53, PARP1, OGG1, ERCC1, ERCC2, and MGMT) were confirmed by quantitative real-time reverse transcription polymerase chain reaction (qRT-PCR). AA exposure also caused a down-regulation of the gene expression of antioxidant enzymes, such as superoxide dismutase, glutathione reductase, and glutathione peroxidase. Moreover, AA treatment led to increased frequency of DNA strand breaks, 8-hydroxydeoxyguanosine-positive nuclei, and micronuclei in a dose-dependent manner in HK-2 cells, possibly as a result
\end{abstract}

Correspondence to: Dr Su-Yin Chiang, School of Chinese Medicine, China Medical University, No 91, Hsueh-Shih Road, Taichung 404, Taiwan

E-mail: sychiang@mail.cmu.edu.tw

*Contributed equally

Key words: aristolochic acid, DNA repair, oxidative DNA damage of the inhibition of DNA repair. These data suggest that oxidative stress plays a role in the cytotoxicity of AA. In addition, our results provide insight into the involvement of down-regulation of DNA repair gene expression as a possible mechanism for AA-induced genotoxicity.

\section{Introduction}

Aristolochic acid (AA), a mixture of structurally-related nitrophenanthrene carboxylic acids, was first detected in Aristolochia clematitis in 1943 (1). Aristolochic acid I (AAI) and Aristolochic acid II (AAII) are the two main active compounds of plants from the genus Aristolochia. Natural products containing AA were used in some pharmaceutical preparations as anti-inflammatory agents; moreover, many formulae containing Aristolochia plants are commonly used as traditional medicine in Eurasia, South America and West Africa (2-4). However, its use gradually declined after Mengs et al reported that it was carcinogenic in rats (5). Most countries now ban or severely restrict the use of plants of the genus Aristolochia based on a multitude of studies that have shown that AA is nephrotoxic in humans (6-10). Aristolochic acid nephropathy (AAN) is characterized by initially normal blood pressure, early severe anemia, mild tubular proteinuria, and rapid progression to renal failure within months up to 2 years (11). The pathology of AAN shows extensive hypocellular interstitial fibrosis associated with tubular atrophy and global glomerular sclerosis (12). Urothelial malignancy of upper urinary tract has been found in $40-46 \%$ of patients exposed to AA $(13,14)$. Two population-based studies by Lai et al found that consumption of AA-containing Chinese herbal products was associated with an increased risk of end-stage renal disease and urinary tract cancer in a dosedependent manner $(15,16)$. This finding is similar to reports that show that high cumulative doses of AA can induce nephropathy in humans (17) and that cumulative doses $>200$ grams of ingested Aristolochia is a significant risk factor for urothelial carcinoma in Belgian AAN patients $(13,14)$.

The carcinogenic effects of AA are considered to be associated with the formation of covalent AA-DNA adducts, which have been detected in affected kidneys of Belgian 
patients with AAN $(18,19)$ and in rodent tissues $(20,21)$. Therefore, it is important to study the mechanism of metabolic activation of AA and the formation of AA-DNA adducts. AAI and AAII are metabolized to reactive intermediates that bind covalently to DNA in vitro and in vivo $(18,20)$. Experiments on the enzymatic activation of AA by xanthine oxidase, DT-diaphorase, and cytosolic nitroreductase have confirmed that nitroreduction is crucial in the metabolic activation of AA (20). Other studies have shown that AA can be activated via nitroreduction by cytochrome P450 (CYP) 1A1, CYP1A2, and NADPH:CYP reductase (22-26). AA forms covalent DNA adducts and deoxyadenosine is the major target of modification. Broschard et al (27) found that dA-AAI, dG-AAI and dA-AAII severely block DNA replication. AA-adenine adducts have a higher mutagenic potential compared with the AA-guanine adducts and $\mathrm{AT} \rightarrow \mathrm{TA}$ transversion mutation has been found in ras gene of AA-exposed rodent tissues and in P53 gene of tissues in AAN patients. Similarly, in AAN patients, one major (dAAAI) and two minor (dG-AAI and dA-AAII) DNA adducts were detected in renal and urinary tissues $(13,18,19,28-30)$.

AA-induced cytotoxicity and genotoxicity have been studied in several biological systems over the past years. Balachandran et al (31) and Li et al (32) have used a porcine proximal tubular epithelial cell line (LLC-PK1) to study DNA damage, cell cycle perturbations, and cell apoptosis induced by AA. Human urinary tract epithelium cells (SVHUC-1), human hepatoma HepG2 cells, and human colorectal cancer cells (HCT 116) (33-35) have also been used to study the cytotoxicity or genotoxicity of AA. Chen et al (36) have shown that more cancer-related genes were significantly altered in target (kidney) tissues than in non-target (liver) tissues in AA-treated rats, suggesting that studies on the toxic effects of AA should be conducted in renal cells.

In this study, we used toxicogenomic analysis to investigate the toxic effects of AA in normal human proximal tubular (HK-2) cells, the target cells of AA. We then tried to elucidate the molecular mechanism of AA-induced toxicity by applying microarray analysis to explore the changes in gene expression patterns in cells exposed to AA. Our results indicate that the decreased expression of DNA repair genes may contribute to the observed increase in $8-\mathrm{OHdG}$ and micronuclei formation in HK-2 cells and may partly explain the genotoxic effects of AA.

\section{Materials and methods}

Cell culture. The human kidney-2 (HK-2), an immortalized cell line of renal proximal tubular epithelial cells from normal adult human kidney, were obtained from Bioresource Collection and Research Center (Hsinchu, Taiwan; BCRC 60097). HK-2 cells were grown in keratinocyte serum-free basal medium (Gibco) supplemented with recombinant epidermal growth factor $(5 \mathrm{ng} / \mathrm{ml})$ and bovine pituitary extract $(50 \mu \mathrm{g} / \mathrm{ml})$ without antibiotics at $37^{\circ} \mathrm{C}$ in a $5 \% \mathrm{CO}_{2}$ incubator.

Drug treatment. Aristolochic acid sodium salt, a mixture of AA I (41\%) and AA II (56\%) (Sigma) was dissolved in double-distilled water and stored at $-30^{\circ} \mathrm{C}$. HK-2 cells were seeded in $75 \mathrm{~T}$ flasks or $25 \mathrm{~T}$ flasks and incubated for overnight before AA treatment. Various concentrations of AA $(10,30,90 \mu \mathrm{M})$ were exposed to HK-2 cells for $24 \mathrm{~h}$ or $30 \mu \mathrm{M}$ AA was exposed for 1, 3, 6, 12 and $24 \mathrm{~h}$. The control cells were placed in equal amounts of water.

\section{3-[4,5-dimethylthiazol-2yl]-2,5-diphenyltetrazolium bromide} (MTT) assay. After AA treatment for varied length of time, MTT was added to $75 \mathrm{~T}$ flasks or $25 \mathrm{~T}$ flasks to reach the final concentration of $0.5 \mathrm{mg} / \mathrm{ml}$. After a 4 -h incubation at $37^{\circ} \mathrm{C}$ in the dark, equal volume of $10 \%$ SDS ( $\mathrm{pH} 2.0)$ was added to dissolve the MTT formazan. When the MTT formazan was dissolved completely, the samples in flasks were transferred to 96-well plates at a volume of $200 \mu \mathrm{l}$ per well. The absorbance was measured at a test wavelength of $570 \mathrm{~nm}$ and a reference wavelength of $630 \mathrm{~nm}$ using a microplate reader. The relative survival of cell growth was calculated by the equation that follows: survival rate $(\%)=$ (Absorbance of AA-treated cells - absorbance of medium only/Absorbance of untreated cells - absorbance of medium only) x $100 \%$.

RNA isolation and toxicogenomic analysis. Total RNAs were extracted from HK-2 cells collected from the dose and timecourse study using RNeasy Mini kit (Qiagen, Valencia, CA). Total RNA was quantified using the Beckman DU800 spectrophotometer (Beckman Coulter, Fullerton, CA). Samples with $\mathrm{A}_{260} / \mathrm{A}_{280}$ ratios $>1.8$ were further evaluated using Aglient 2100 Bioanalyzer (Agilent Technologies, Santa Clara, CA). The RNA samples with an RNA integrity number $>8.0$ were subjected to microarray analysis.

Microarray analysis was performed in triplicate as described previously (37). Briefly, fluorescence-labeled RNA targets were prepared from $5 \mu \mathrm{g}$ of total RNA samples using Message Amp ${ }^{\mathrm{TM}}$ aRNA kit (Ambion, Austin, TX) and Cy5 dye (Amersham Pharmacia, Piscataway, NJ). Triplicate fluorescent targets were hybridized overnight to the Human Whole Genome OneArray ${ }^{\mathrm{TM}}$ (Phalanx Biotech Group, Hsinchu, Taiwan), and non-specific targets were washed by three different washing steps, and the slides were dried by centrifugation and immediately scanned by an Axon 4000 scanner (Molecular Devices, Sunnyvale, CA). The Cy5 fluorescent intensity of each spot was analyzed by genepix 4.1 software (Molecular Devices). The signal intensity of each spot was corrected by subtracting background signals in the surrounding area. We filtered out control probes and background-corrected signal intensity of each spot. Spots were then normalized by the Limma package of the $\mathrm{R}$ program (38). Normalized data were tested for differential expression using the Gene Expression Pattern Analysis Suite v3.1 (39). We used the 'geneSetTest' function in the Limma package to test which biological pathways were affected by AA in HK-2 cells. This function computes a p-value to test the hypothesis that the selected genes in a pathway tend to be differentially expressed. We have submitted the original microarray data to Gene Expression Omnibus (GEO), series number GSE18243. Two samples (mock, treatment) and one series (mock + treatment) are included. The sample numbers are GSM455880 (treatment) and GSM455881 (mock). 
Table I. Primer sequences of selected genes for qRT-PCR.

Gene

Primer sequence

ERCC1

Sense: 5'-TCTCCCGGGTGACTGAATGT-3'

Antisense: 5'-GCGATGAGCTGTTCCAGAGAT-3'

ERCC2

Sense: 5'-GGCAAAGTGTCCGAGGGAAT-3'

Antisense: 5'-CCTTGAGAATGCGGCTCTGT-3'

GADD45B

Sense: 5'-TGTACGAGTCGGCCAAGTTG-3'

Antisense: 5'-ATTTGCAGGGCGATGTCATC-3'

MGMT

Sense: 5'-CCTGGCTGAATGCCTATTTCC-3'

Antisense: 5'-TGTCTGGTGAACGACTCTTGCT-3'

NAIP

Sense: 5'-CTGGATGCTGTCCCCTGTTAA-3'

Antisense: 5'-AGGAGCTGGTCACAGATGATACTG-3'

OGG1

Sense: 5'-TTCCAAGAGGTGGCTCAGAAAT-3'

Antisense: 5'-CGATGTTGTTGTTGGAGGAACA-3'

PARP

Sense: 5'-GGAGTCGGCGATCTTGGA-3'

Antisense: 5'-AGTAATAGGCATCGCTCTTGAAGAC-3'

TP53

Sense: 5'-GGGTTAGTTTACAATCAGCCACATT-3'

Antisense: 5'-GGGCCTTGAAGTTAGAGAAAATTCA-3'

Quantitative real-time reverse transcription polymerase chain reaction ( $q R T-P C R)$. The expression levels of DNA repair-related genes were further validated by qRT-PCR. Total RNA was used as a template for reverse transcription using the RNA Reverse Transcription Kit from ABI (Applied Biosystems). Quantitative PCR was performed using $1 \mu \mathrm{l}$ of cDNA, 2X SYBR-Green PCR Master Mix (Applied Biosystems, Foster City, CA, USA). The reaction conditions were as follows: $10 \mathrm{~min}$ at $95^{\circ} \mathrm{C}$ followed by 40 cycles of $15 \mathrm{sec}$ at $95^{\circ} \mathrm{C}, 1 \mathrm{~min}$ at $60^{\circ} \mathrm{C}$. Each assay was run on an Applied Biosystems 7300 real-time PCR system in triplicates. Relative amount of mRNA was calculated using the comparative $\mathrm{C}_{\mathrm{T}}$ method. The primer sets for selected genes are shown in Table I.

Alkaline single-cell gel electrophoresis (comet assay). HK-2 cells were treated with $10,30,90,150 \mu \mathrm{M}$ of AA for 3 or $24 \mathrm{~h}$, and $100 \mu \mathrm{M}$ of $\mathrm{H}_{2} \mathrm{O}_{2}$ (positive control) for $30 \mathrm{~min}$. After treatment with AA, cells were harvested for the examination of DNA damage by using the Comet assay. Seventy microliters of $0.5 \%$ of normal melting point agarose (NMP) and $0.5 \%$ low melting point agarose (LMP) in PBS $(\mathrm{pH} 7.4)$ were covered on the slides, and allowed to dry. Ten microliters of cell suspension $\left(1 \times 10^{4}\right.$ cells) were gently mixed with $70 \mu 1$ of $0.5 \%$ of LMP in PBS (pH 7.4), and take $70 \mu 1$ of this suspension rapidly layered onto the slides precoated with the mixtures of $0.5 \%$ of NMP and $0.5 \%$ of LMP, and covered with a coverslip. Then the coverslip was removed and the cells embedded in agarose were immersed in a freshly made lysis solution $(2.5 \mathrm{M} \mathrm{NaCl}, 100 \mathrm{mM}$ $\mathrm{Na}_{2}$ EDTA, $10 \mathrm{mM}$ Tris and $1 \%$ Triton $\mathrm{X}-100$ at $\mathrm{pH} 10.0$ ) for $1 \mathrm{~h}$ at $4^{\circ} \mathrm{C}$. The slides then were placed on a horizontal gel electrophoresis tank and the DNA was allowed to unwind for $20 \mathrm{~min}$ in freshly prepared alkaline electrophoresis buffer containing $0.3 \mathrm{M}$ of $\mathrm{NaOH}$ and $1 \mathrm{mM}$ of $\mathrm{Na}_{2}$ EDTA ( $\mathrm{pH}>13)$. Thereafter, electrophoresis $(25 \mathrm{~V}, 300 \mathrm{~mA})$ was conducted for $30 \mathrm{~min}$ at $4^{\circ} \mathrm{C}$. After electrophoresis, the slides were then soaked in a cold neutralizing buffer $(0.4 \mathrm{M}$ Tris buffer, $\mathrm{pH} 7.5$ ) to neutralize the excess alkali at $4^{\circ} \mathrm{C}$ for $15 \mathrm{~min}$. Slides were dried in methanol for $5 \mathrm{~min}$, and stained with propidium iodide $(5 \mu \mathrm{g} / \mathrm{ml})$. Comet length was analyzed using CometScore software.

Immunostaining for 8-OHdG. HK-2 cells were seeded on coverslips and treated with AA $(10,30$ or $90 \mu \mathrm{M})$ for $24 \mathrm{~h}$. The coverslips were fixed with cold acetone for $10 \mathrm{~min}$ at $-20^{\circ} \mathrm{C}$, air-dried at room temperature, and stored at $-20^{\circ} \mathrm{C}$ if not processed immediately. Before staining, the cells were rehydrated in PBS and treated with RNase $(100 \mu \mathrm{g} / \mathrm{ml})$ in Tris buffer ( $\mathrm{pH} 7.5 ; 10 \mathrm{mM}$ Tris- $\mathrm{HCl}, 0.4 \mathrm{M} \mathrm{NaCl}$ ) at $37^{\circ} \mathrm{C}$ for $50 \mathrm{~min}$ and proteinase $\mathrm{K}(1 \mu \mathrm{g} / \mathrm{ml})$ for $7 \mathrm{~min}$ at room temperature. Samples were denatured in $4 \mathrm{~N} \mathrm{HCl}$ for $5 \mathrm{~min}$ and neutralized with $50 \mathrm{mM}$ Tris-base for $4 \mathrm{~min}$. In order to block endogenous peroxidase, samples were incubated with $3 \% \mathrm{H}_{2} \mathrm{O}_{2}$ in methanol for $15 \mathrm{~min}$. Immunocytochemistry was performed using a Novolink Polymer Detection System (Novocastra). Briefly, non-specific binding was blocked by protein block (RE7166, 0.4\% Casein in phosphate-buffered saline) for $30 \mathrm{~min}$ at room temperature and incubated with anti-8-hydroxydeoxyguanosine $(8-\mathrm{OHdG})$ monoclonal antibody N45.1 (Fukuroi, Japan, 1:200 dilution) overnight at $4^{\circ} \mathrm{C}$. After rinsing with PBS, post primary block (RE7167, 10\% animal serum) was incubated for $30 \mathrm{~min}$, followed by NovoLink $^{\mathrm{TM}}$ polymer (RE7168, anti-mouse/rabbit IgG-Poly-HRP) 
$\mathbf{A}$

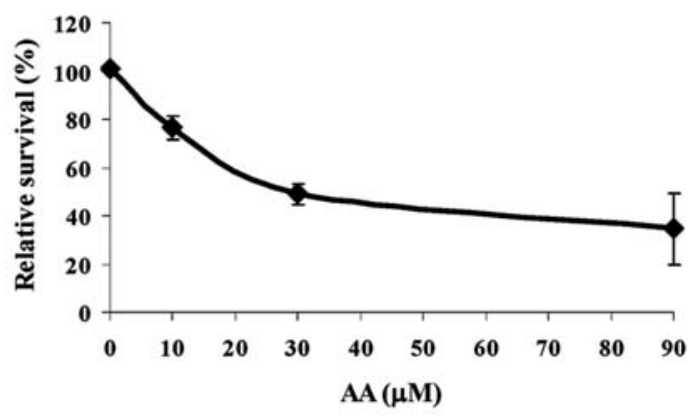

B

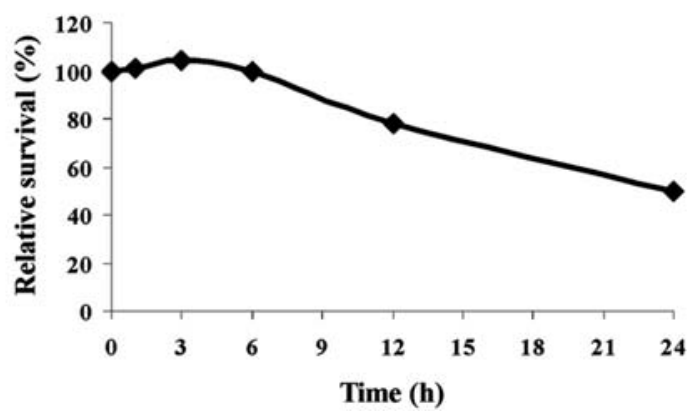

Figure 1. The cytotoxicity of various doses and time intervals of AA in HK-2 cells. HK-2 cells in $75 \mathrm{~T}$ flasks or $25 \mathrm{~T}$ flasks were treated with 10, 30 and $90 \mu \mathrm{M}$ of $\mathrm{AA}(\mathrm{A})$ and $30 \mu \mathrm{M}$ of AA for $1,3,6,12$ and $24 \mathrm{~h}(\mathrm{~B})$. The cell viability was measured by MTT assay. Values are mean \pm standard deviation of three independent experiments. ${ }^{* * *} \mathrm{P}<0.001$, indicate significant difference as compared to control group.

for $30 \mathrm{~min}$. Slides were treated with diaminobenzidine to localize peroxidase and mounted on a cover glass. 8-OHdGstained cells were then detected under light microscopy.

Western blot analysis. HK-2 cells treated with or without AA were harvested, lysed in lysis buffer, and centrifuged at
$10,000 \times \mathrm{g}$ for $5 \mathrm{~min}$. The supernatant was collected and protein concentrations were determined using the Bradford colorimetric assay. After denaturing by heating at $95^{\circ} \mathrm{C}$ for $5 \mathrm{~min}, 45 \mu \mathrm{g}$ of each protein lysate were loaded in each lane in sample buffer, separated on $10 \%$ SDS-PAGE. The separated proteins were transferred onto nitrocellulose membranes and blocked with 5\% non-fat milk for $1 \mathrm{~h}$ at room temperature. The membranes were incubated overnight at $4^{\circ} \mathrm{C}$ with the rabbit anti-OGG1 antibody (Novus Biologicals, Littleton, CO), mouse anti-p21 antibody, rabbit anti-c-fos antibody, mouse anti-caspase-3 antibody, mouse anti-Bax antibody and mouse anti- $\alpha$-tubulin antibody (Santa Cruz Biotechnology) at 1:1000 dilution. After washing $10 \mathrm{~min}$ with TBS-Tween three times, the membranes were incubated with a 1:10000 dilution of goat anti-rabbit horseradish peroxidase (HRP)-conjugated antibody (Santa Cruz Biotechnology) for $1 \mathrm{~h}$ at room temperature. Finally, the blots were visualized by ECL.

Micronucleus test. HK-2 cells were seeded on coverslips and treated with AA (10 or $30 \mu \mathrm{M})$. After 24-h incubation, cytochalasin B was added to a final concentration of $3 \mu \mathrm{g} / \mathrm{ml}$ for 16-24 h to obtain binucleated cells. The cells were fixed with methanol at $4^{\circ} \mathrm{C}$ for $30 \mathrm{~min}$ and air-dried for $10 \mathrm{~min}$. For staining, the slides were incubated with acridine orange $(0.1 \mathrm{mg} / \mathrm{ml})$ in the dark for $10 \mathrm{~min}$, wash twice with buffer, and mounted for microscopy. The analysis was performed under fluorescent microscope with $488 \mathrm{~nm}$ excitation wavelength. Small round or ovoid-shaped intracytoplasmic bodies with a diameter of 1/3-1/20 of the main nucleus in binucleated cells were scored as micronuclei. A total of 1000 binucleated cells from 2 slides were scored for each treatment. The averages of three independent experiments are shown.

Statistical analysis. Data are presented as mean \pm SD. Student's t-test was used for comparisons between the control and AA-treated groups. A value of $\mathrm{p}<0.05$ was considered to be statistically significant.

Table II. Biological processes significantly regulated by AA in HK-2 cells.

\begin{tabular}{lcccc}
\hline & \multicolumn{3}{c}{ P-values } \\
\cline { 2 - 5 } Biological processes & Genes & $10 \mu \mathrm{M} \mathrm{AA}$ & $30 \mu \mathrm{M} \mathrm{AA}$ & $90 \mu \mathrm{M} \mathrm{AA}$ \\
\hline DNA repair & 166 & $3.15 \times 10^{-7}$ & $7.70 \times 10^{-5}$ & $1.75 \times 10^{-7}$ \\
Response to DNA damage stimulus & 122 & $5.40 \times 10^{-7}$ & $2.00 \times 10^{-4}$ & $2.20 \times 10^{-6}$ \\
Mitochondrial transport & 28 & $1.00 \times 10^{-4}$ & $3.50 \times 10^{-3}$ & $1.99 \times 10^{-2}$ \\
Lipid metabolic process & 195 & $3.00 \times 10^{-4}$ & $2.00 \times 10^{-1}$ & $1.90 \times 10^{-3}$ \\
Apoptosis & 295 & $4.00 \times 10^{-4}$ & $1.60 \times 10^{-3}$ & $1.19 \times 10^{-5}$ \\
Extracellular matrix organization and biogenesis & 17 & $1.80 \times 10^{-3}$ & $9.43 \times 10^{-6}$ & $8.21 \times 10^{-2}$ \\
DNA-dependent DNA replication & 42 & $2.10 \times 10^{-3}$ & $1.00 \times 10^{-3}$ & $2.29 \times 10^{-2}$ \\
Extracellular structure organization and biogenesis & 13 & $4.30 \times 10^{-3}$ & $1.31 \times 10^{-2}$ & $3.40 \times 10^{-1}$ \\
Regulation of cell cycle & 181 & $1.27 \times 10^{-2}$ & $2.33 \times 10^{-2}$ & $8.71 \times 10^{-6}$ \\
Negative regulation of cell proliferation & 116 & $1.09 \times 10^{-2}$ & $1.93 \times 10^{-1}$ & $2.33 \times 10^{-2}$ \\
\hline
\end{tabular}

The biological pathways affected by AA in HK-2 cells were examined by GeneSetTest' function in the Limma package. This function computes a p-value to test the hypothesis that the selected genes in a pathway tend to be differentially expressed $(n=3)$. 


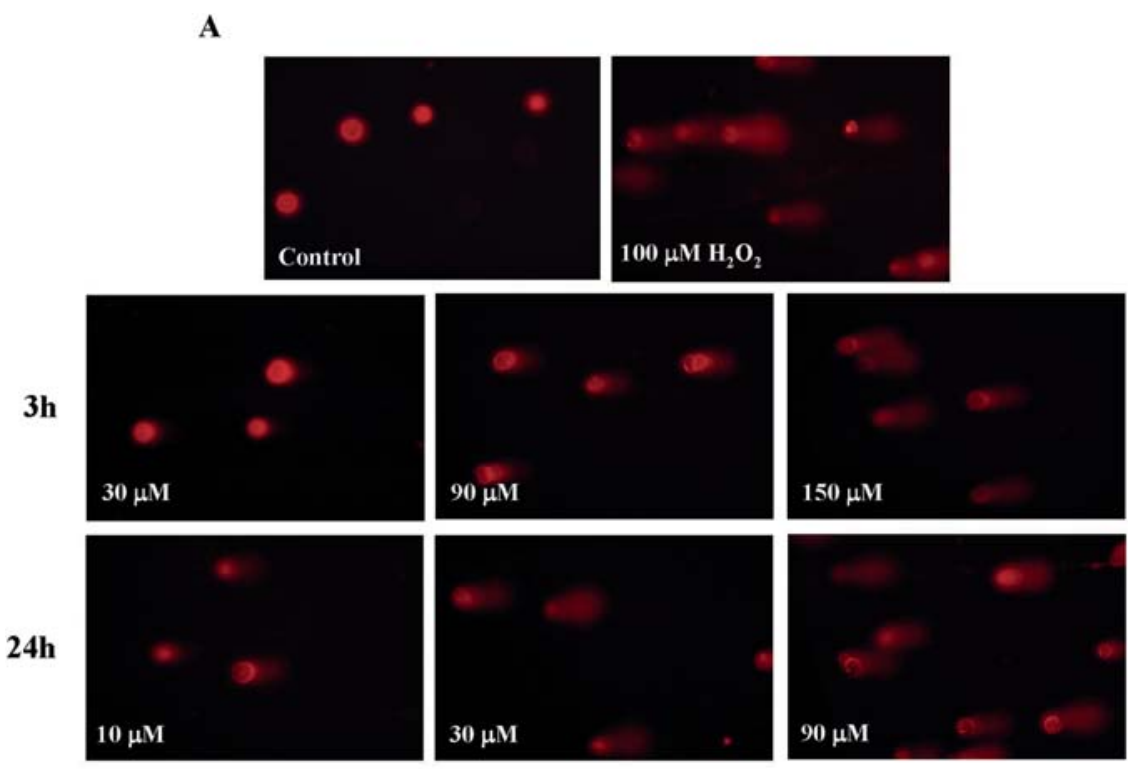

B
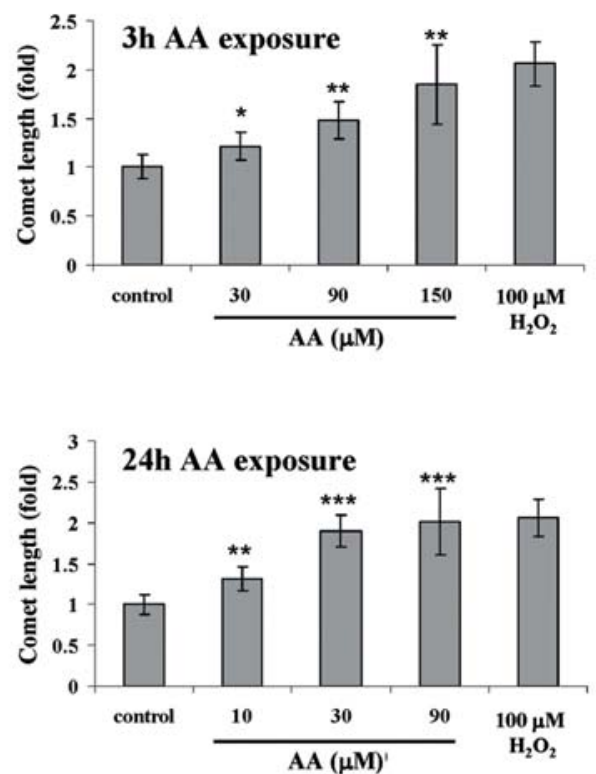

Figure 2. Induction of DNA strand breaks in HK-2 cells. AA induced DNA damage in HK-2 cells was examined by Comet assay and DNA gel electrophoresis. The HK-2 cells were incubated with various concentrations of AA for 3 or $24 \mathrm{~h}$ and DNA damage was determined by Comet assay. The cell pellet was resuspended in LMP agarose for comet analysis and cells embedded in agarose were lysed. Thereafter, DNA was allowed to unwind under alkaline buffer and electrophoresis was conducted under $25 \mathrm{~V}$ for $30 \mathrm{~min}$. Finally, slides were neutralized, dried, and then stained with propidium iodide (5 $\mu \mathrm{g} / \mathrm{ml}$ ). (A) Representative photomicrographs from three independent experiments (original magnification, $\mathrm{x} 200$ ). (B) The quantification of comet length. $\mathrm{P}<0.05$, ${ }^{* *} \mathrm{P}<0.01,{ }^{* * *} \mathrm{P}<0.001$.

\section{Results}

Cytotoxicity. We examined cell viability in $25 \mathrm{~T}$ flasks or $75 \mathrm{~T}$ flasks by MTT assay after exposing HK-2 cells to various concentrations of AA $(10,30$ or $90 \mu \mathrm{M})$ for 24 h or to $30 \mu \mathrm{M}$ AA for 1, 3, 6, 12 and $24 \mathrm{~h}$. There is little or no effect on cell survival at low dose of AA $(10 \mu \mathrm{M})$ or in short exposure time to $30 \mu \mathrm{M}$ AA (up to $12 \mathrm{~h}$ ). A 24-h exposure to 10,30 , and $90 \mu \mathrm{M}$ of $\mathrm{AA}$ resulted in a dose-dependent decrease in kidney cell growth with an $\mathrm{IC}_{50}$ value of $30 \mu \mathrm{M}$. The relative survival rate of cells treated with $10 \mu \mathrm{M}$ AA was 76.5 \pm 5.0 , that of cells exposed to $30 \mu \mathrm{M}$ AA was $49.0 \pm 4.2$, and that of cells treated with $90 \mu \mathrm{M}$ AA was $34.6 \pm 14.7$ (Fig. 1A). The relative survival of cells treated with $30 \mu \mathrm{M}$ AA for 1, 3, 6, 12 and 24 h was: $101.1 \pm 0.9,104.0 \pm 0.8,99.8 \pm 1.0,77.9 \pm 0.4$ and $50.0 \pm 0.2$ (Fig. 1B).

Gene expression profiles. We used unsupervised analysis to predict significant differences in gene expression in HK-2 cells in response to 10,30 and $90 \mu \mathrm{M}$ of AA treatment. As shown in Table II, genes in the DNA repair pathway were the most significantly regulated. Selected differentially expressed genes related to stress response, cell cycle, apoptosis, fibrogenic response, and biotransformation were listed in Table III. The selected DNA repair genes significantly regulated by AA in HK2 cells included genes in pathways of 
Table III. Selected stress response-, cell cycle-, apoptosis-, fibrogenic response- and biotransformation-related genes significantly regulated by AA in HK-2 cells.

\begin{tabular}{|c|c|c|c|c|}
\hline \multirow[b]{2}{*}{ Gene symbol } & \multirow[b]{2}{*}{ Annotation } & \multicolumn{3}{|c|}{ Fold change $\pm \mathrm{SD}$} \\
\hline & & $10 \mu \mathrm{M}$ AA & $30 \mu \mathrm{M}$ AA & $90 \mu \mathrm{M}$ AA \\
\hline \multicolumn{5}{|c|}{ Stress response } \\
\hline DDIT3 & DNA-damage-inducible transcript 3 & - & $1.66 \pm 0.16^{\mathrm{a}}$ & $4.03 \pm 0.12^{\mathrm{b}}$ \\
\hline GADD45B & Growth arrest and DNA-damage-inducible, $\beta$ & $2.68 \pm 0.16^{\mathrm{a}}$ & $3.66 \pm 0.19^{\mathrm{a}}$ & $3.00 \pm 0.15^{\mathrm{a}}$ \\
\hline GADD45G & Growth arrest and DNA-damage-inducible, $\gamma$ & - & $5.08 \pm 0.33^{\mathrm{a}}$ & $13.36 \pm 0.32^{b}$ \\
\hline GPX3 & Glutathione peroxidase 3 (plasma) & $-1.87 \pm 0.19^{\mathrm{a}}$ & $-1.76 \pm 0.16^{\mathrm{b}}$ & - \\
\hline GPX6 & Glutathione peroxidase 6 (olfactory) & - & $-2.56 \pm 0.22^{\mathrm{a}}$ & $-2.10 \pm 0.17^{\mathrm{a}}$ \\
\hline GSR & Glutathione reductase & - & $-2.61 \pm 0.12^{\mathrm{b}}$ & $-2.42 \pm 0.20^{\mathrm{a}}$ \\
\hline HSPA14 & Heat shock $70 \mathrm{kDa}$ protein 14 & $1.89 \pm 0.07^{\mathrm{c}}$ & $1.85 \pm 0.10^{\mathrm{b}}$ & $1.41 \pm 0.06^{\mathrm{b}}$ \\
\hline HSPC047 & HSPC047 protein & $1.97 \pm 0.25^{\mathrm{a}}$ & $4.19 \pm 0.25^{\mathrm{b}}$ & $4.60 \pm 0.27^{\mathrm{b}}$ \\
\hline HSPC065 & HSPC065 protein & $1.87 \pm 0.29^{\mathrm{a}}$ & $1.91 \pm 0.29^{\mathrm{a}}$ & - \\
\hline MT1X & Metallothionein 1X & $-1.83 \pm 0.23^{\mathrm{a}}$ & $-1.45 \pm 0.12^{\mathrm{a}}$ & - \\
\hline SOD3 & Superoxide dismutase 3 , extracellular & $-1.51 \pm 0.16^{\mathrm{a}}$ & $-2.09 \pm 0.11^{b}$ & - \\
\hline \multicolumn{5}{|l|}{ Cell cycle } \\
\hline CCND2 & Cyclin D2 & $-2.25 \pm 0.06^{c}$ & $-2.89 \pm 0.05^{\mathrm{c}}$ & $-5.69 \pm 0.15^{b}$ \\
\hline CCNE1 & Cyclin E1 & $-1.25 \pm 0.25^{\mathrm{a}}$ & $-1.50 \pm 0.20^{a}$ & $-1.84 \pm 0.15^{\mathrm{b}}$ \\
\hline CDKL1 & Cyclin-dependent kinase-like 1 (CDC2-related kinase) & $-1.68 \pm 0.21^{\mathrm{a}}$ & $-1.79 \pm 0.24^{\mathrm{a}}$ & - \\
\hline CDKN1A & Cyclin-dependent kinase inhibitor 1A (p21) & $-1.64 \pm 0.17^{\mathrm{a}}$ & - & - \\
\hline CDKN1B & Cyclin-dependent kinase inhibitor 1B (p27, Kip1) & $-1.42 \pm 0.08^{\mathrm{b}}$ & - & $-2.82 \pm 0.11^{\mathrm{c}}$ \\
\hline CDKN2B & $\begin{array}{l}\text { Cyclin-dependent kinase inhibitor } 2 \mathrm{~B} \\
(\mathrm{p} 15, \text { inhibits CDK4) }\end{array}$ & $-1.54 \pm 0.12^{b}$ & $-1.33 \pm 0.11^{a}$ & $-1.58 \pm 0.12^{b}$ \\
\hline CDKN3 & $\begin{array}{l}\text { Cyclin-dependent kinase inhibitor } 3 \text { (CDK2- } \\
\text { associated dual specificity phosphatase) }\end{array}$ & $-1.91 \pm 0.25^{\mathrm{a}}$ & $-2.49 \pm 0.09^{c}$ & - \\
\hline E2F3 & E2F transcription factor 3 & $-1.21 \pm 0.07^{\mathrm{a}}$ & $-1.51 \pm 0.12^{\mathrm{a}}$ & $-1.84 \pm 0.06^{\mathrm{c}}$ \\
\hline MDM2 & Mdm2, p53 binding protein (mouse) & $-1.41 \pm 0.11^{\mathrm{a}}$ & $-1.57 \pm 0.08^{b}$ & - \\
\hline RB1 & Retinoblastoma 1 (including osteosarcoma) & - & $-1.44 \pm 0.18^{\mathrm{a}}$ & $-2.24 \pm 0.20^{b}$ \\
\hline RBL2 & Retinoblastoma-like 2 (p130) & - & $-2.25 \pm 0.18^{\mathrm{b}}$ & $-1.49 \pm 0.13^{\mathrm{a}}$ \\
\hline TP53 & Tumor protein p53 (Li-Fraumeni syndrome) & $-1.90 \pm 0.14^{\mathrm{a}}$ & $-1.50 \pm 0.08^{a}$ & $-1.34 \pm 0.05^{\mathrm{b}}$ \\
\hline WEE1 & WEE1 homolog (S.pombe) & $-2.00 \pm 0.18^{b}$ & $-2.01 \pm 0.23^{\mathrm{a}}$ & $-2.58 \pm 0.24^{b}$ \\
\hline \multicolumn{5}{|l|}{ Apoptosis } \\
\hline BAX & BCL2-associated X protein & - & - & $1.28 \pm 0.07^{\mathrm{a}}$ \\
\hline BCL2L2 & BCL2-like 2 & - & $-2.26 \pm 0.10^{\mathrm{b}}$ & $-1.95 \pm 0.06^{\mathrm{b}}$ \\
\hline BNIP3 & BCL2/adenovirus E1B $19 \mathrm{kDa}$ interacting protein 3 & $-2.04 \pm 0.19^{b}$ & $-2.76 \pm 0.20^{\mathrm{b}}$ & $-3.60 \pm 0.17^{b}$ \\
\hline CASP3 & Caspase-3, apoptosis-related cysteine protease & $1.05 \pm 0.15^{\mathrm{a}}$ & $1.40 \pm 0.17^{\mathrm{a}}$ & $1.34 \pm 0.13^{\mathrm{a}}$ \\
\hline CCL2 & Chemokine (C-C motif) ligand 2 & - & $-1.86 \pm 0.19^{a}$ & $-3.54 \pm 0.31^{\mathrm{b}}$ \\
\hline NAIP & Apoptosis inhibitor protein & $3.25 \pm 0.38^{\mathrm{a}}$ & $4.91 \pm 0.35^{\mathrm{b}}$ & $3.25 \pm 0.10^{c}$ \\
\hline PRKCA & Protein kinase $\mathrm{C}, \alpha$ & - & $-1.41 \pm 0.09^{\mathrm{b}}$ & $-2.92 \pm 0.17^{b}$ \\
\hline TNFRSF1B & Tumor necrosis factor receptor superfamily, member 1B & $1.67 \pm 0.21^{\mathrm{a}}$ & $1.61 \pm 0.25^{\mathrm{a}}$ & $2.35 \pm 0.37^{\mathrm{a}}$ \\
\hline TNFRSF21 & Tumor necrosis factor receptor superfamily, member 21 & $1.46 \pm 0.09^{\mathrm{a}}$ & $1.33 \pm 0.13^{\mathrm{a}}$ & $1.88 \pm 0.12^{\mathrm{b}}$ \\
\hline TNFSF6 & Tumor necrosis factor (ligand) superfamily, member 6 & - & $3.46 \pm 0.25^{\mathrm{a}}$ & $4.55 \pm 0.32^{\mathrm{b}}$ \\
\hline \multicolumn{5}{|l|}{$\begin{array}{l}\text { Fibrogenic } \\
\text { response }\end{array}$} \\
\hline FOS & v-fos FBJ murine osteosarcoma viral oncogene homolog & - & $1.37 \pm 0.17^{\mathrm{a}}$ & $1.97 \pm 0.20^{\mathrm{b}}$ \\
\hline ITGB7 & Integrin, $\beta 7$ & $5.01 \pm 0.40^{\mathrm{a}}$ & $12.22 \pm 0.12^{c}$ & $15.36 \pm 0.19^{c}$ \\
\hline LTBP2 & Latent transforming growth factor $\beta$ binding protein 2 & $1.51 \pm 0.17^{\mathrm{a}}$ & $2.47 \pm 0.20^{\mathrm{b}}$ & $2.50 \pm 0.16^{\mathrm{b}}$ \\
\hline MMP2 & Matrix metalloproteinase 2 & $-1.75 \pm 0.31^{\mathrm{a}}$ & $-2.10 \pm 0.22^{\mathrm{a}}$ & $-1.64 \pm 0.21^{\mathrm{a}}$ \\
\hline NBL1 & Neuroblastoma, suppression of tumorigenicity 1 & $-1.12 \pm 0.12^{\mathrm{a}}$ & $-1.37 \pm 0.16^{\mathrm{a}}$ & $-1.27 \pm 0.11^{\mathrm{a}}$ \\
\hline PLAU & Plasminogen activator, urokinase & $1.32 \pm 0.10^{\mathrm{a}}$ & $1.54 \pm 0.08^{b}$ & - \\
\hline SMAD4 & SMAD, mothers against DPP homolog 4 (Drosophila) & - & $1.77 \pm 0.14^{\mathrm{a}}$ & $1.55 \pm 0.07^{\mathrm{b}}$ \\
\hline STAT1 & Signal transducer and activator of transcription $1,91 \mathrm{kDa}$ & $-2.28 \pm 0.11^{\mathrm{b}}$ & $-3.33 \pm 0.19^{b}$ & $-4.21 \pm 0.10^{\mathrm{b}}$ \\
\hline TBRG4 & Transforming growth factor $ß$ regulator 4 & $1.71 \pm 0.13^{\mathrm{b}}$ & $2.64 \pm 0.08^{c}$ & $4.17 \pm 0.21^{b}$ \\
\hline
\end{tabular}


Table III. Continued.

\begin{tabular}{|c|c|c|c|c|}
\hline \multirow[b]{2}{*}{ Gene symbol } & \multirow[b]{2}{*}{ Annotation } & \multicolumn{3}{|c|}{ Fold change \pm SD } \\
\hline & & $10 \mu \mathrm{M} \mathrm{AA}$ & $30 \mu \mathrm{M}$ AA & $90 \mu \mathrm{M}$ AA \\
\hline \multicolumn{5}{|c|}{ Biotransformation } \\
\hline CYP1A1 & Cytochrome P450, family 1 , subfamily A, polypeptide 1 & $3.22 \pm 0.24^{\mathrm{a}}$ & $4.91 \pm 0.29^{b}$ & $4.85 \pm 0.25^{\mathrm{b}}$ \\
\hline EPHX1 & Epoxide hydrolase 1, microsomal (xenobiotic) & - & $1.33 \pm 0.06^{\mathrm{a}}$ & $1.11 \pm 0.01^{\mathrm{c}}$ \\
\hline GNMT & Glycine N-methyltransferase & $4.49 \pm 0.19^{b}$ & $7.94 \pm 0.13^{\mathrm{b}}$ & $7.04 \pm 0.09^{c}$ \\
\hline GSTA2 & Glutathione S-transferase A2 & - & $-1.85 \pm 0.09^{b}$ & $-2.18 \pm 0.26^{\mathrm{a}}$ \\
\hline GTDC1 & Glycosyltransferase-like 1 & $-2.00 \pm 0.14^{\mathrm{b}}$ & $-2.60 \pm 0.14^{b}$ & $-4.34 \pm 0.22^{b}$ \\
\hline MGST2 & Microsomal glutathione S-transferase 2 & - & $-1.95 \pm 0.19^{a}$ & $-2.09 \pm 0.18^{a}$ \\
\hline MGST3 & Microsomal glutathione S-transferase 3 & $-1.49 \pm 0.11^{\mathrm{b}}$ & $-2.15 \pm 0.14^{\mathrm{a}}$ & $-1.90 \pm 0.13^{\mathrm{a}}$ \\
\hline POR & P450 (cytochrome) oxidoreductase & - & $1.46 \pm 0.08^{\mathrm{b}}$ & $2.53 \pm 0.12^{\mathrm{c}}$ \\
\hline $\mathrm{XDH}$ & Xanthine dehydrogenase & - & $-2.28 \pm 0.31^{\mathrm{a}}$ & $-2.05 \pm 0.36^{\mathrm{a}}$ \\
\hline
\end{tabular}

$\mathrm{SD}$, standard deviation. ${ }^{\mathrm{a}} \mathrm{P}<0.05,{ }^{\mathrm{b}} \mathrm{P}<0.01,{ }^{\mathrm{c}} \mathrm{P}<0.001$ as compared to control cells, $\mathrm{n}=3$.

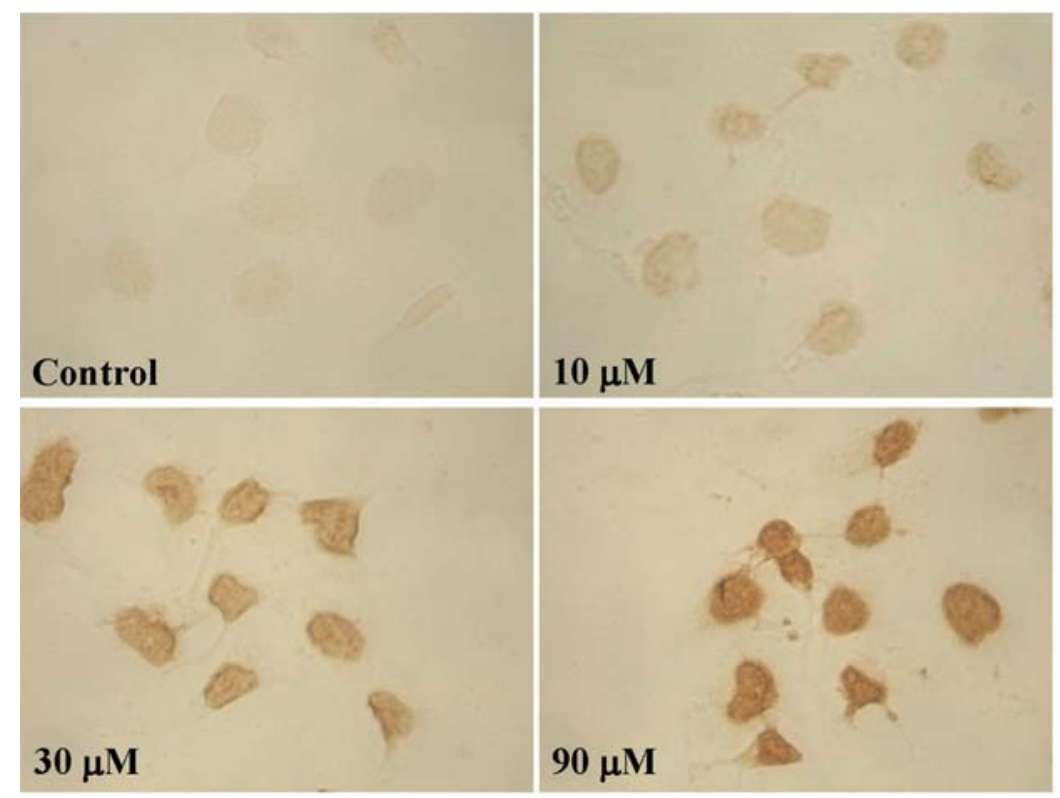

Figure 3. Induction of 8-OHdG by AA in HK-2 cells. HK-2 cells were treated with 10, 30, $90 \mu \mathrm{M}$ of AA for $24 \mathrm{~h}$. Then, the cells were immunostained for 8-OHdG using the N45.1 monoclonal antibody (1:200). Nuclei of HK-2 cells presented strong positive staining for 8-OHdG after AA exposure. Representative photomicrographs from three independent experiments are shown (original magnification, $\mathrm{x} 400$ ).

base excision repair, nucleotide excision repair, direct reverse repair, and mismatch repair (Table IV).

Tables V and VI show the comparison of expression of selected DNA repair genes and stress response genes from the dose and time-course response study by microarray and qRT-PCR in AA-treated HK-2 cells. A total of eight genes, including five DNA repair genes (ERCC1, ERCC2, MGMT, OGG1, and PARP1), two apoptosis-related genes (TP53 and NAIP), and stress one response-related gene (GADD45B) were chosen for verification by qRT-PCR. The expression levels of DNA repair-related genes in qRT-PCR correlated with the general trend of expression in the microarray analysis. Among genes involved in DNA repair pathway and stress response, the down-regulation of ERCC1, ERCC2, MGMT, OGG1 and TP53 by AA observed in the microarray analysis was confirmed by qRT-PCR, with the most prominent effects at $24 \mathrm{~h}$ after AA exposure (Table VI).

Comet assay. AA induced DNA damage in HK-2 cells was examined by Comet assay. The results from Comet assay are presented in Fig. 2. Higher concentrations of AA led to longer DNA migration smears (Comet tail) (Fig. 2), and indicated that more DNA was damaged in the cells. These results showed that AA induced DNA damaged in HK-2 cells in a dose-dependent manner.

Immunostaining assessment of $8-O H d G$. We evaluated the extent of oxidative damage of DNA using immunocytochemical staining of $8-\mathrm{OHdG}$, the most widely measured oxidative DNA damage. Fig. 3 shows representative 
Table IV. Selected DNA repair genes significantly regulated by AA in HK-2 cells.

Fold change \pm SD

\begin{tabular}{|c|c|c|c|c|}
\hline Gene symbol & Annotation & $10 \mu \mathrm{M}$ AA & $30 \mu \mathrm{M}$ AA & $90 \mu \mathrm{M}$ AA \\
\hline \multicolumn{5}{|l|}{$\begin{array}{l}\text { Base excision } \\
\text { repair }\end{array}$} \\
\hline APEX2 & APEX nuclease (apurinic/apyrimidinic endonuclease) 2 & $-1.52 \pm 0.16^{\mathrm{a}}$ & $-1.51 \pm 0.19^{a}$ & $-2.06 \pm 0.15^{b}$ \\
\hline LIG3 & Ligase III, DNA, ATP-dependent & $-1.80 \pm 0.16^{\mathrm{a}}$ & $-1.60 \pm 0.09^{b}$ & $-1.13 \pm 0.10$ \\
\hline MPG & N-methylpurine-DNA glycosylase & $-1.89 \pm 0.13^{b}$ & $-2.28 \pm 0.11^{b}$ & $1.02 \pm 0.15$ \\
\hline OGG1 & 8-oxoguanine DNA glycosylase & $-1.81 \pm 0.36$ & $-2.53 \pm 0.23^{\mathrm{a}}$ & $-2.12 \pm 0.42$ \\
\hline PARP1 & Poly (ADP-ribose) polymerase family, member 1 & $-1.32 \pm 0.17$ & $-1.68 \pm 0.17^{\mathrm{a}}$ & $-2.21 \pm 0.15^{\mathrm{b}}$ \\
\hline SMUG1 & $\begin{array}{l}\text { Single-strand selective monofunctional uracil DNA } \\
\text { glycosylase }\end{array}$ & $-1.18 \pm 0.22$ & $-1.51 \pm 0.11^{\mathrm{a}}$ & $-1.64 \pm 0.16^{\mathrm{a}}$ \\
\hline \multicolumn{5}{|c|}{$\begin{array}{l}\text { Nucleotide excision } \\
\text { repair }\end{array}$} \\
\hline ERCC1 & $\begin{array}{l}\text { Excision repair cross-complementing rodent repair } \\
\text { deficiency, complementation group } 1\end{array}$ & $-2.53 \pm 0.22^{b}$ & $-2.76 \pm 0.20^{b}$ & $1.16 \pm 0.16$ \\
\hline ERCC2 & $\begin{array}{l}\text { Excision repair cross-complementing rodent repair } \\
\text { deficiency, complementation group } 2\end{array}$ & $4.32 \pm 0.12^{\mathrm{c}}$ & $-3.79 \pm 0.11^{\mathrm{c}}$ & $-1.48 \pm 0.08^{b}$ \\
\hline PNKP & Polynucleotide kinase 3'-phosphatase & $-4.18 \pm 0.24^{b}$ & $-3.51 \pm 0.18^{b}$ & $-1.26 \pm 0.10$ \\
\hline RAD23A & RAD23 homolog A (S. cerevisiae) & $-1.88 \pm 0.15^{b}$ & $-1.48 \pm 0.17^{\mathrm{a}}$ & $-1.21 \pm 0.15$ \\
\hline RAD23B & RAD23 homolog B (S. cerevisiae) & $-1.38 \pm 0.16^{\mathrm{a}}$ & $-1.53 \pm 0.16^{\mathrm{a}}$ & $-2.33 \pm 0.21^{\mathrm{a}}$ \\
\hline \multicolumn{5}{|l|}{$\begin{array}{l}\text { Direct reverse } \\
\text { repair }\end{array}$} \\
\hline MGMT & O-6-methylguanine-DNA methyltransferase & $-1.32 \pm 0.29$ & $-2.60 \pm 0.31^{\mathrm{a}}$ & $-1.56 \pm 0.32$ \\
\hline \multicolumn{5}{|c|}{ Mismatch Repair } \\
\hline POLD4 & Polymerase (DNA-directed), $\delta 4$ & $-1.56 \pm 0.12^{b}$ & $-1.78 \pm 0.13^{b}$ & $1.21 \pm 0.14$ \\
\hline \multicolumn{5}{|l|}{$\begin{array}{l}\text { Homologous } \\
\text { recombination }\end{array}$} \\
\hline NBS1 & Nijmegen breakage syndrome 1 (nibrin) & $-1.49 \pm 0.34$ & $-1.86 \pm 0.24^{\mathrm{a}}$ & $-4.32 \pm 0.26^{b}$ \\
\hline RAD18 & RAD18 homolog (S. cerevisiae) & $-1.86 \pm 0.20^{\mathrm{a}}$ & $-1.61 \pm 0.13^{\mathrm{b}}$ & $-1.39 \pm 0.11^{\mathrm{a}}$ \\
\hline RAD54L & RAD54-like (S. cerevisiae) & $-1.38 \pm 0.09^{\mathrm{a}}$ & $-1.35 \pm 0.12^{\mathrm{a}}$ & $1.42 \pm 0.13^{\mathrm{a}}$ \\
\hline \multicolumn{5}{|c|}{$\begin{array}{l}\text { Non-homologous } \\
\text { end joining }\end{array}$} \\
\hline BTG2 & BTG family, member 2 & $-2.65 \pm 0.26^{\mathrm{b}}$ & $-2.29 \pm 0.25^{\mathrm{a}}$ & $-1.54 \pm 0.22^{\mathrm{a}}$ \\
\hline CIB1 & Calcium and integrin binding 1 (calmyrin) & $-1.61 \pm 0.12^{b}$ & $-1.83 \pm 0.12^{\mathrm{b}}$ & $1.64 \pm 0.09^{\mathrm{b}}$ \\
\hline RFC3 & Replication factor C (activator 1) 3, $38 \mathrm{kDa}$ & $-1.27 \pm 0.46$ & $-1.54 \pm 0.12^{\mathrm{a}}$ & $-2.18 \pm 0.16^{\mathrm{b}}$ \\
\hline RFC4 & Replication factor C (activator 1) 4, $37 \mathrm{kDa}$ & $-1.36 \pm 0.19$ & $-1.61 \pm 0.21^{\mathrm{a}}$ & $-1.69 \pm 0.21^{\mathrm{a}}$ \\
\hline
\end{tabular}

$\mathrm{SD}$, standard deviation. ${ }^{\mathrm{a}} \mathrm{P}<0.05,{ }^{\mathrm{b}} \mathrm{P}<0.01,{ }^{\mathrm{c}} \mathrm{P}<0.001$ as compared to control cells, $\mathrm{n}=3$.

immunostaining of $8-\mathrm{OHdG}$ in $\mathrm{HK}-2$ cells treated with or without AA. 8-OHdG was localized mainly in the nucleus of both control and AA-treated cells, and the staining intensity of $8-\mathrm{OHdG}$ was greater in AA-treated group especially at the concentration of $90 \mu \mathrm{M}$ than in the control group.

Western blot analysis. Protein levels of c-fos, OGG1, caspase-3, Bax, and p21 were analyzed by Western blot analysis in cells exposed to various concentration of AA $(0,10,30$ and $90 \mu \mathrm{M}$ ) for $24 \mathrm{~h}$ (Fig. 4). As expected, AA caused a significant dose-dependent increase in the expression of $\mathrm{c}$-fos, caspase-3, and Bax proteins in comparison to controls, and a decrease in the expression of OGG1 and p21 proteins.

Micronucleus test. The genotoxicity of AA was examined by the micronucleus test as a marker of chromosome alteration. Treatment with AA for $24 \mathrm{~h}$ induced a dose-dependent increase in the frequency of micronuclei formation in binucleated HK-2 cells. The frequency of micronuclei in control was $3.5 \pm 0.4$, that of cells exposed to $10 \mu \mathrm{M}$ AA was 10.2 \pm 1.4 , and that of cells treated with $30 \mu \mathrm{M}$ AA was $13.9 \pm 1.9$ (Fig. 5). 
Table V. Expression of selected DNA repair genes and stress response genes from dose response study by microarray and qRT-PCR in AA-treated HK-2 cells.

\begin{tabular}{|c|c|c|c|c|c|c|}
\hline \multirow[b]{2}{*}{ Gene } & \multicolumn{3}{|c|}{ Microarray (Fold change \pm SD) } & \multicolumn{3}{|c|}{ qRT-PCR (Fold change) } \\
\hline & $10 \mu \mathrm{M} \mathrm{AA}$ & $30 \mu \mathrm{M}$ AA & $90 \mu \mathrm{M}$ AA & $10 \mu \mathrm{M}$ AA & $30 \mu \mathrm{M}$ AA & $90 \mu \mathrm{M} \mathrm{AA}$ \\
\hline ERCC1 & $-2.53 \pm 0.22^{\mathrm{a}}$ & $-2.76 \pm 0.20^{\mathrm{b}}$ & $-1.34 \pm 0.05^{\mathrm{b}}$ & -1.35 & -1.27 & -1.16 \\
\hline ERCC2 & $-4.32 \pm 0.12^{c}$ & $-3.79 \pm 0.11^{\mathrm{c}}$ & $-1.48 \pm 0.08^{b}$ & -1.75 & -1.39 & -1.69 \\
\hline GADD45B & $2.68 \pm 0.16^{\mathrm{b}}$ & $3.66 \pm 0.19^{b}$ & $2.99 \pm 0.15^{\mathrm{b}}$ & 2.00 & 2.31 & 1.87 \\
\hline MGMT & $-1.32 \pm 0.29$ & $-2.60 \pm 0.31^{\mathrm{a}}$ & $-1.56 \pm 0.32$ & -1.56 & -2.63 & -2.56 \\
\hline NAIP & $3.25 \pm 0.38^{\mathrm{a}}$ & $4.91 \pm 0.35^{b}$ & $3.25 \pm 0.10^{\mathrm{c}}$ & 1.94 & 1.48 & 1.46 \\
\hline OGG1 & $-1.81 \pm 0.36$ & $-2.53 \pm 0.23^{b}$ & $-2.12 \pm 0.42$ & -1.49 & -1.56 & -1.56 \\
\hline PARP1 & $-1.32 \pm 0.17$ & $-1.68 \pm 0.17^{\mathrm{a}}$ & $-2.21 \pm 0.15^{\mathrm{b}}$ & 1.13 & -1.14 & -1.54 \\
\hline TP53 & $-1.90 \pm 0.14^{\mathrm{a}}$ & $-1.50 \pm 0.08^{\mathrm{a}}$ & $-1.34 \pm 0.05^{\mathrm{b}}$ & -1.82 & -1.15 & 1.03 \\
\hline
\end{tabular}

$\mathrm{SD}$, standard deviation. ${ }^{\mathrm{a}} \mathrm{P}<0.05,{ }^{\mathrm{b}} \mathrm{P}<0.01,{ }^{\mathrm{c}} \mathrm{P}<0.001$ as compared to control cells, $\mathrm{n}=3$ for microarray and $\mathrm{qRT}$-PCR analysis.

Table VI. Expression of selected DNA repair genes from time-course study by microarray and qRT-PCR in AA-treated HK-2 cells.

\begin{tabular}{|c|c|c|c|c|c|c|c|c|}
\hline \multirow[b]{2}{*}{ Gene } & \multicolumn{4}{|c|}{ Microarray (Fold change \pm SD) } & \multicolumn{4}{|c|}{ qRT-PCR (Fold change) } \\
\hline & $1 \mathrm{~h}$ & $3 \mathrm{~h}$ & $6 \mathrm{~h}$ & $24 \mathrm{~h}$ & $1 \mathrm{~h}$ & $3 \mathrm{~h}$ & $6 \mathrm{~h}$ & $24 \mathrm{~h}$ \\
\hline ERCC1 & $-1.09 \pm 0.28$ & $-1.03 \pm 0.24$ & $1.54 \pm 0.06^{b}$ & $-2.76 \pm 0.20^{b}$ & 1.05 & 1.02 & 1.07 & -1.27 \\
\hline ERCC2 & $1.08 \pm 0.11$ & $-1.26 \pm 0.16$ & $1.06 \pm 0.20$ & $-3.79 \pm 0.11^{c}$ & 1.11 & -1.14 & -1.23 & -1.39 \\
\hline MGMT & $1.05 \pm 0.49$ & $1.89 \pm 0.29$ & $1.14 \pm 0.49$ & $-2.60 \pm 0.31^{\mathrm{a}}$ & -1.02 & -1.12 & -1.20 & -2.63 \\
\hline OGG1 & $1.09 \pm 0.56$ & $-1.10 \pm 0.28$ & $-1.48 \pm 0.63$ & $-2.53 \pm 0.23^{b}$ & 1.13 & -1.16 & -1.27 & -1.56 \\
\hline TP53 & $1.04 \pm 0.09$ & $1.24 \pm 0.19$ & $1.02 \pm 0.13$ & $-1.50 \pm 0.08^{\mathrm{a}}$ & 1.05 & -1.45 & -1.85 & -1.15 \\
\hline
\end{tabular}

$\mathrm{SD}$, standard deviation. ${ }^{\mathrm{a}} \mathrm{P}<0.05,{ }^{\mathrm{b}} \mathrm{P}<0.01,{ }^{\mathrm{c}} \mathrm{P}<0.001$ as compared to control cells, $\mathrm{n}=3$ for microarray and $\mathrm{qRT}$-PCR analysis.

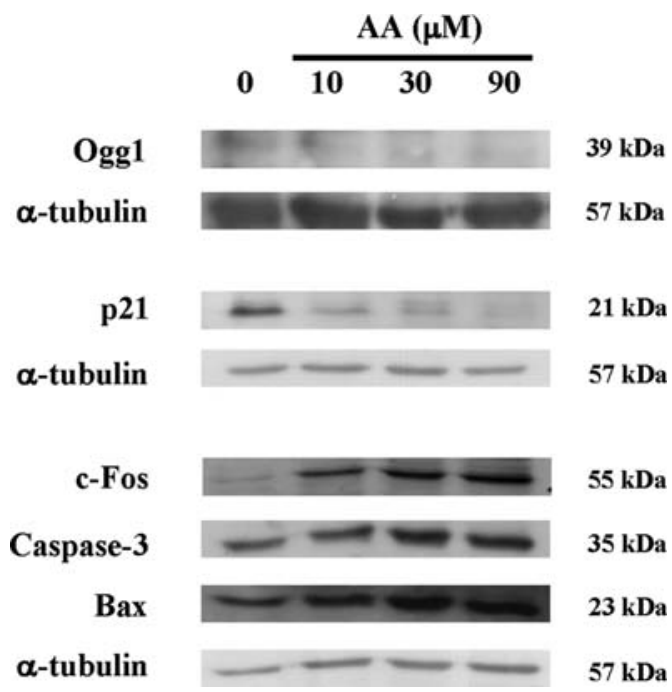

Figure 4. Effect of AA on the expression of DNA repair, cell cycle, apoptosis-related proteins. HK-2 cells were treated with $10,30,90 \mu \mathrm{M}$ of AA for $24 \mathrm{~h}$. Protein samples ( $45 \mu \mathrm{g}$ each) were resolved by SDS-polyacrylamide gel electrophoresis and transferred to nitrocellulose membranes. After blocking, the membranes were incubated overnight with antibodies specific to Ogg1, p21, c-fos, caspase-3, Bax and $\alpha$-tubulin. They were then blotted with a secondary antibody conjugated with horseradish peroxidase, followed by detection using ECL substrate. $\alpha$-tubulin was used as loading control.

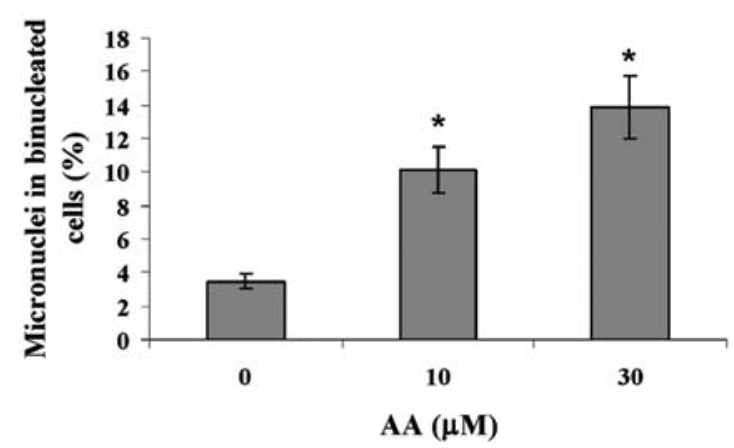

Figure 5. Induction of micronuclei formation by AA in HK-2 cells. HK-2 cells were treated with 10 and $30 \mu \mathrm{M}$ of AA. Following treatment, the medium was replaced with fresh medium containing cytochalasin B (3 $\mu \mathrm{g} /$ $\mathrm{ml}$ ) to obtain binucleated cells. Cells were cultured for at least $16 \mathrm{~h}$ prior to fixation and staining with acridine orange solution $(0.1 \mathrm{mg} / \mathrm{ml})$. The extent of chromosome damage was examined by scoring micronuclei formation in 1000 binucleated cells. ${ }^{*} \mathrm{P}<0.05, \mathrm{n}=3$.

\section{Discussion}

In the present study, we used toxicogenomic analysis to clarify the molecular mechanisms of AA-induced toxic effects in normal human proximal tubular cells. Among the genes that 
were regulated by AA, we found that genes in DNA repair pathway were the most significantly altered after exposure to 10,30 and $90 \mu \mathrm{M}$ of AA. Furthermore, some genes related to stress response, cell cycle, apoptosis, fibrogenic response, and biotransformation were also significantly regulated by all AA treatments in HK-2 cells (Table III). Furthermore, the results from qRT-PCR analysis of the 8 selected genes (ERCC1, ERCC2, GADD45B, MGMT, NAIP, OGG1, PARP1, TP53) confirmed the results from the microarray analysis (Tables V and VI). AA significantly inhibited the mRNA expression of DNA repair-associated genes, including ERCC1, ERCC2, MGMT, OGG1, and PARP1. After AA treatment, the down-regulation of the gene and protein expression of OGG1, a specific DNA glycosylase that excises 8-OHdG, may partly explain the observed increased number of 8-OHdG-stained cells and increased levels of single strand breaks in AA-treated cells. Subsequently, the induction of DNA damage and the repression of DNA repair gene expression by AA resulted in a dose-dependent increase in the frequency of micronuclei formation in binucleated HK-2 cells (Fig. 5). Our results show the involvement of oxidative damage on AA-induced cytotoxicity and provide new insight into the possible involvement of DNA repair inhibition on AA-induced genotoxicity.

Herbal drugs derived from Aristolochia spp. have been known since antiquity and the anti-inflammatory properties of AA encouraged the development of pharmaceutical preparations in Germany until Mengs and co-workers observed that AA is a strong carcinogen in rats in 1982. Several studies showed that AA can induce cytotoxic effects in human colon cancer HCT 116 cells, porcine renal LLC-PK1 cells, and opossum kidney (OK) cell line. The HK-2 cells used in our study were more sensitive to the cytotoxicity of AA than HCT 116 cells (35), and OK cells (40). The $\mathrm{IC}_{50}$ of $24 \mathrm{~h} \mathrm{AA}$ treatment for HK-2 cells and HCT 116 cells was 30 and $100 \mu \mathrm{M}$, respectively. Incubation of OK cells with AA (10 or $20 \mu \mathrm{M}$ ) for $24 \mathrm{~h}$ was shown not to affect cell viability. The findings from those studies point out the importance of using cultured cells derived from normal human target organs of a specific chemical when its toxic effects to human are examined.

Our toxicogenomic analysis revealed that genes in biological processes of DNA repair, response to DNA damage stimuli, apoptosis, extracellular matrix organization and biogenesis, DNA-dependent DNA replication, and regulation of cell cycle were significantly regulated by AA in HK-2 cells. Among those processes, however, genes in the DNA repair pathway were the most significantly regulated (Table II). Among stress response-related genes, GADD45B (growth arrest and DNA-damage-inducible, $\beta$ gene) was significantly up-regulated by AA at all three of the tested concentrations (Table III). GADD45B, a member of a family of structurally related proteins including GADD45A and GADD45G, has been implicated in stress signaling in response to physiological and genotoxic stressors (41), which results in either cell cycle arrest, DNA repair, cell survival or apoptosis. On the other hand, aberrant expression of GADD45 has also been implicated in the development of cancer (42). Our finding that GADD45B was up-regulated by AA is consisted with that reported previously (43), in which GADD45B was induced by the alkylating agent MMS (methylmethane sulfonate) and sorbitol.

Previous studies in LLC-PK1 cells showed that AAI induced apoptotic damage by inhibiting the increase of intracellular free calcium concentration. Our study from microarray analysis revealed the increase expression of the proapoptotic factors, BAX and caspase, after AA exposure. BAX (BCL2-associated X protein gene) was up-regulated at high dose $(90 \mu \mathrm{M})$ in HK-2 cells (Table III). Caspase-3 was up-regulated at $30 \mu \mathrm{M}$ AA treatment and these results are similar to reports from Balachandran et al (31). They found that the caspase activity was induced by AAI, AAII, AAIa, and AAVIIIa in LLC-PK1 cells. Our Western blot analysis showed AA induced a dose-dependent increase of BAX and caspase- 3 protein. NAIP (apoptosis inhibitor protein) is overexpressed in most human cancers and inhibition of its function results in increased apoptosis. The role of upregulation of NAIP in AA-induced cytotoxicity needs further investigation.

Among cell cycle-related genes, the gene and protein expression levels of CDKN1A (cyclin-dependent kinase inhibitor 1A, p21) were down-regulated after $10 \mu \mathrm{M}$ AA treatment. CDKN1A mediates the p53-dependent cell cycle G1 phase arrest in response to a variety of stress signals, including genotoxic stress, hypoxia, and oncogene activation. Our results were opposite to those reported (35) in p53-null cells after a 48 -h exposure to AA $(100 \mu \mathrm{M})$ in HCT 116 cell line. Previous data from Chang (33) showed that AA mixture (AAM; $41 \%$ AA I, 56\% AA II) can cause arrest in the G0/G1 phase (from 37.6 to $49.2 \%$ ) in human urinary tract epithelium cells (SV-HUC-1), suggesting that AA-induced cell cycle arrest at the G0/G1 phase is associated with cyclin $\mathrm{E} / \mathrm{cdk} 2$ complex (the cdk inhibitor). They also found that the levels of cell cycle control protein (include p53, p21 and p27) were increased in a concentration-dependent manner after AA exposure for $24 \mathrm{~h}$. Our Western blot analysis found that $\mathrm{p} 21$ protein expression was dramatically decreased after exposure to all three doses of AA.

MDM2, another gene involved in the cell cycle, is a target gene of the transcription factor p53. Our observation that MDM2 is significantly down-regulated by AA is similar to that reported in AA-treated wild-type rats (44). Overexpression of MDM2 can result in excessive inactivation of p53, thereby diminishing its tumor suppressor function. The tumor suppressor p53 also affects the cell cycle, apoptosis, and tumorigenesis through interactions with other proteins. p53 is activated in response to DNA damage due to ultraviolet light, chemicals, or ionizing radiation. It is generally believed that the activity of p53 is primarily governed by its protein level. The immediate early gene c-fos is a cellular protooncogene that belongs to the fos family of transcription factors. The c-fos protein codes for a major nuclear target that dimerizes with c-Jun to form AP-1 transcription factor complexes, which in turn participate in many cellular events including cell proliferation, differentiation, apoptosis, and stress responses. Fos was significantly up-regulated by AA treatment $(90 \mu \mathrm{M})$ in HK-2 cells in our study but was shown to be significantly down-regulated in HCT 116 cancer cell line (35).

AA was shown to causes chromosomal aberration in human lymphocytes in vitro and increases the mutation 
frequency of lacZ and CII locus in lambda/lacZ transgenic mice in vivo. Cosyns et al have found that urothelial carcinomas are associated with overexpression of $\mathrm{p} 53$ protein in AAN patients (45). Lord et al (46) detected a specific AAGto-TAG mutation in codon 139 of exon 5 in TP53 in DNA from one patient with AAN-associated urothelial carcinoma. That mutation in the TP53 gene might trigger tumorigenesis in AAN patients in the same way that AA-induced mutations in codon 61 of H-ras trigger tumorigenesis in rodents (47). In our study, microarray expression profile and quantification by RT-PCR showed that 10,30 and $90 \mu \mathrm{M}$ treatment of AA could down-regulate TP53. These results differ from those reported by Simoes et al (35) in which no significant difference in $\mathrm{p} 53$ expression was found in p53-WT HCT 116 cells after a 24-h exposure to AA $(100 \mu \mathrm{M})$. Many studies have showed that TP53 is involved in the nucleotide excision repair pathway and that loss of TP53 will enhance DNA damage (48-50). Shen et al (50) showed that arsenic can cause genotoxicity by inhibiting the p53-medicated nucleotide excision repair. Tsai et al (49) showed that arecoline, which is a major alkaloid of areca nut, can repress p53-activated DNA repair and induce DNA damage in human epithelial cells. Our microarray and qRT-PCR data showed that AA caused the down-regulation of TP53 which may lead to the decrease of DNA repair capability and subsequently induce tumorigenesis. Further study is needed to clarify the changes of p53 gene and protein expression after AA treatment.

Table IV shows the selected DNA repair genes that were significantly regulated by AA in HK-2 cells. Among those genes, nucleotide excision repair (NER) genes are most likely involved in repairing AA-DNA adducts. This is because NER genes are known to play a key role in preventing toxicity and mutation frequencies for bulky, distortive DNA lesions. The NER process includes damage recognition, local opening of the DNA duplex around the lesion, dual incision of the damaged DNA strand, gap repair synthesis, and strand ligation (51). The NER pathway splits into two sub-pathways: transcription-coupled repair (TCR) and global genomic repair (GGR). They are fundamentally identical except in steps of damage recognition. In humans, NER is a major protector against the carcinogenic effect of UV light and inborn defects such as xeroderma pigmentosum (XP) (52). ERCC1 (excision repair cross-complementing group 1) and ERCC2 (XPD) (excision repair cross-complementing rodent repair deficiency, complementation group 2; xeroderma pigmentosum D) belong to NER-deficient complementation groups. The ERCC1 domain is a part of endonuclease (5's incision) during DNA strand dual incision step (53) and overexpression of ERCC1 mRNA is related to cisplatin resistance in gastric, ovarian and lung cancer (54-56). ERCC1 expression was also reported to be a specific target for oxidative stress-induced modification of NER (57). ERCC2 (XPD) is involved in both GGR and TCR and is an integral member of the basal transcription factor BTF2/TFIIH complex. Defects in this gene can result in three different disorders, the cancer-prone syndrome xeroderma pigmentosum complementation group $\mathrm{D}$, trichothiodystrophy and Cockayne syndrome (58). Our study found that ERCC1 and ERCC2 were both downregulated by AA. Similar findings were reported by Cheng et al (59) and Wei et al (60) they found that low mRNA levels of DNA-repair genes (including ERCCC1 and ERCC2) in lymphocytes were associated with high relative risk for head and neck cancer and lung cancer. The decreased expression of ERCC1 by AA treatment is also in accordance to the study in which arsenic can diminish the expression of the nucleotide excision repair genes ERCC1, XPF (ERCC4), and XPB (ERCC3) (61). Another DNA repair gene, MGMT (O-6-methylguanine-DNA methyltransferase), was downregulated in $30 \mu \mathrm{M}$ AA treatment but this result is opposite to that in AA-treated rats (44).

It is well known that reactive oxygen species (ROS) can cause oxidative damage to DNA. Our transcriptome analysis revealed that AA exposure caused a down-regulation of the gene expression of antioxidant enzymes, such as superoxide dismutase, glutathione reductase, and glutathione peroxidase. Furthermore, we found that AA induced an oxidative stress characterized by an induction of $8-\mathrm{OHdG}$ and DNA strand breaks. These results suggest that the involvement of oxidative stress in AA-induced toxicity. 8-OHdG, one of the major abundant oxidative DNA damage markers which can efficiently repair by a glycosylase, OGG1 (62-65). In this study, gene expression of OGG1 was decreased in cells exposed to AA. Microarray analysis showed a 2.5-fold decrease and qRT-PCR showed a 1.6-fold decrease in OGG1 gene expression in cells exposed to AA. Furthermore, there was a dose-dependent increase in 8-OH-dG immunostaining, probably as a result of decreased OGG1 expression. We also used comet assay to examine DNA damage in HK-2 cells after exposure to AA. The results showed a significant increase in the tail movement at all concentrations (Fig. 2) $(\mathrm{p}<0.05)$. These findings were similar to those reported by $\mathrm{Wu}$ et al (34). They used comet and micronucleus test to identify the genotoxicity of AA and found a clear dosedependent manner (25-200 $\mu \mathrm{M}$ AA) increase in tail DNA movement and a significant increase in frequencies of micronuclei (12.5-50 $\mu \mathrm{M}$ AA) in human hepatoma HepG2 cells (34). They also found that AA at concentrations $\geq 50 \mu \mathrm{M}$ caused a significant increase in NO and 8-OHdG levels and assumed that high-dose AA exerted genotoxicity probably via NO in HepG2 cells. It is worthwhile to note that the expression and activity of hOGG1 is thought to be primarily regulated by p53 (66). In our study, OGG1 and TP53 were both significantly down-regulated in cells exposed to AA.

In conclusion, in this study, we applied toxicogenomic analysis to explore the changes in gene expression after AA exposure. The genes that were most significantly regulated by AA treatment at doses of 10,30 and $90 \mu \mathrm{M}$ involved in DNA repair, cell cycle, apoptosis, and response to DNA damage. All treatments with AA effectively down-regulated genes involved in DNA repair. The inhibition of DNA repair gene expression by AA was further confirmed by qRT-PCR. Moreover, comet assay, immunostaining, and micronucleus assay showed that AA caused oxidative DNA damage and chromosome damage. The down-regulation of OGG1 and other DNA repair genes by AA may subsequently have led to the observed increase in $8-\mathrm{OHdG}$ and micronuclei in HK-2 cells, thereby leading to increased DNA damage. Our results provide new insight into the involvement of down-regulation of DNA repair gene expression as a possible mechanism for AA-induced mutagenesis and carcinogenesis. 


\section{Acknowledgements}

We thank Mr. Wei-Shuen Shen, Miss Pei-Yi Lee, Mr. Chi-Cheng Lu and Miss Wei-Pin Huang for their technical assistance. This study was supported by grants from the National Research Program for Genomic Medicine, the National Science and Technology Program for Agricultural Biotechnology, the National Science Council, the Committee on Chinese Medicine and Pharmacy of the Department of Health (CCMP 96-RD-201 and CCMP 97-RD-201), and China Medical University (CMU95-051).

\section{References}

1. Rosenmund $\mathrm{H}$ and Reichstein $\mathrm{T}$ : Zur Kenntnis der Aristolochiasäure. Pharm Acta Helv 18: 243-261, 1943.

2. Zhang G, Shimokawa S, Mochizuki M, Kumamoto T, Nakanishi W, Watanabe T, Ishikawa T, Matsumoto K, Tashima K, Horie S, Higuchi Y and Dominguez OP: Chemical constituents of Aristolochia constricta: antispasmodic effects of its constituents in guinea-pig ileum and isolation of a diterpenolignan hybrid. J Nat Prod 71: 1167-1172, 2008.

3. Messiano GB, Vieira L, Machado MB, Lopes LM, de Bortoli SA and Zukerman-Schpector J: Evaluation of insecticidal activity of diterpenes and lignans from Aristolochia malmeana against Anticarsia gemmatalis. J Agric Food Chem 56: 2655-2659, 2008.

4. Debelle FD, Vanherweghem JL and Nortier JL: Aristolochic acid nephropathy: a worldwide problem. Kidney Int 74: 158-169, 2008

5. Mengs U, Lang W and Poch J-A: The carcinogenic action of aristolochic acid in rats. Arch Toxicol 51: 107-119, 1982

6. Vanherweghem JL, Depierreux M, Tielemans C, et al: Rapidly progressive interstitial renal fibrosis in young women: association with slimming regimen including Chinese herbs. Lancet 341: 387-391, 1993

7. Vanhaelen M, Vanhaelen-Fastre R, But P and Vanherweghem JL: Identification of aristolochic acid in Chinese herbs. Lancet 343: 174, 1994.

8. Stengel B and Jones E: [End-stage renal insufficiency associated with Chinese herbal consumption in France]. Nephrologie 19: 15-20, 1998.

9. Lord GM, Tagore R, Cook T, et al: Nephropathy caused by Chinese herbs in the UK. Lancet 354: 481-482, 1999.

10. Arlt VM, Stilborova M and Schmeiser HH: Aristolochic acid as a probable human cancer hazard in herbal remedies: a review. Mutagenesis 17: 265-277, 2002.

11. Cosyns JP, Jadou IM, Squifflet JP, et al: Chinese herbs nephropathy: a clue to Balkan endemic nephropathy? Kidney Int 45: 1680-1688, 1994.

12. Depierreux M, Damme BV, Vanden HK, et al: Pathologic aspects of a newly described nephropathy related to the prolonged use of Chinese herbs. Am J Kidney Dis 24: 172-180, 1994.

13. Nortier JL, Martinez MC, Schmeiser HH, Arlt VM, Bieler CA, Petein M, Depierreux MF, De Pauw L, Abramowicz D, Vereerstraeten P and Vanherweghem JL: Urothelial carcinoma associated with the use of a Chinese herb (Aristolochia fangchi). N Engl J Med 342: 1686-1692, 2000.

14. Cosyns JP, Jadoul M, Squifflet JP, Van Cangh PJ and van Ypersele de Strihou C: Urothelial malignancy in nephropathy due to Chinese herbs. Lancet 344: 188, 1994.

15. Lai MN, Wang SM, Chen PC, Chen YY and Wang JD: Population-based case-control study of Chinese herbal products containing aristolochic acid and urinary tract risk. J Natl Cancer Inst 102: 1-8, 2009

16. Lai MN, Lai JN, Chen PC, Hsieh SC, Hu FC and Wang JD: Risks of kidney failure associated with consumption of herbal products containing $\mathrm{Mu}$ Tong or Fangchi: a population based case-control study. Am J Kidney Dis (In press).

17. Martinez MC, Nortier J, Vereestraeten $P$ and Vanherweghem JL: progression rate of Chinese herb nephropathy: impact of Aristolochia fangchi ingested dose. Nephrol Dial Transplant 17: 408-412, 2002.

18. Schmeiser HH, Bieler CA, Wiessler M, van YdSC and Cosyns JP Detection of DNA adducts formed by aristolochic acid in rena tissue from patients with Chinese herbs nephropathy. Cancer Res 56: 2025-2028, 1996.
19. Bieler CA, Stiborova M, Wiessler M, Cosyns JP, van Ypersele de Strihou $\mathrm{C}$ and Schmeiser HH: ${ }^{32} \mathrm{P}$-post-labelling analysis of DNA adducts formed by aristolochic acid in tissues from patients with Chinese herbs nephropathy. Carcinogenesis 18: 1063-1067, 1997

20. Schmeiser HH, Schoepe KB and Wiessler M: DNA adduct formation of aristolochic acid I and II in vitro and in vivo. Carcinogenesis 9: 297-303, 1988.

21. Stiborova M, Fernando RC, Schmeiser HH, Frei E, Pfau W and Wiessler M: Characterization of DNA adducts formed by aristolochic acids in the target organ (forestomach) of rats by ${ }^{32} \mathrm{P}$-postlabelling analysis using different chromatographic procedures. Carcinogenesis 15: 1187-1192, 1994.

22. Stiborova M, Bieler CA, Wiessler M and Frei E: The anticancer agent ellipticine on activation by cytochrome P450 forms covalent DNA adducts. Biochem Pharmacol 62: 1675-1684, 2001.

23. Stiborova M, Frei E, Breuer A, Wiessler M and Schmeiser HH: Evidence for reductive activation of carcinogenic aristolochic acids by prostaglandin $\mathrm{H}$ synthase - (32)P-postlabeling analysis of DNA adduct formation. Mutat Res 493: 149-160, 2001.

24. Stiborova M, Frei E, Wiessler M and Schmeiser HH: Human enzymes involved in the metabolic activation of carcinogenic aristolochic acids: evidence for reductive activation by cytochromes P450 1A1 and 1A2. Chem Res Toxicol 14: 1128-1137, 2001.

25. Stiborova M, Hajek M, Frei E and Schmeiser HH: Carcinogenic and nephrotoxic alkaloids aristolochic acids upon activation by NADPH: cytochrome P450 reductase form adducts found in DNA of patients with Chinese herbs nephropathy. Gen Physiol Biophys 20: 375-392, 2001

26. Stiborova M, Schmeiser HH, Breuer A and Frei E: Evidence for activation of carcinogenic o-anisidine by prostaglandin $\mathrm{H}$ synthase: ${ }^{32} \mathrm{P}$-postlabelling analysis of DNA adduct formation. Gen Physiol Biophys 20: 267-279, 2001.

27. Broschard TH, Wiessler M and Schmeiser HH: Effect of sitespecifically located aristolochic acid DNA adduct on in vitro DNA synthesis by human DNA polymerase alpha. Cancer Lett 98: 47-56, 1995

28. Arlt VM, Pfohl-Leszkowicz A, Cosyns J and Schmeiser HH: Analyses of DNA adducts formed by ochratoxin A and aristolochic acid in patients with Chinese herbs nephropathy. Mutat Res 494: 143-150, 2001.

29. Gillerot G, Jadoul M, Arlt VM, van Ypersele De Strihou C, Schmeiser HH, But PP, Bieler CA and Cosyns JP: Aristolochic acid nephropathy in a Chinese patient: time to abandon the term 'Chinese herbs nephropathy'? Am J Kidney Dis 38: E26, 2001.

30. Lord GM, Cook T, Arlt VM, Schmeiser HH, Williams G and Pusey CD: Urothelial malignant disease and Chinese herbal nephropathy. Lancet 358: 1515-1516, 2001

31. Balachandran P, Wei F, Lin RC, Khan IA and Pasco DS: Structure activity relationships of aristolochic acid analogues: toxicity in cultured renal epithelial cells. Kidney Int 67: 1797-1805, 2005.

32. Li Y, Liu Z, Guo X, Shu J, Chen Z and Li L: Aristolochic acid I-induced DNA damage and cell cycle arrest in renal tubular epithelial cells in vitro. Arch Toxicol 80: 524-532, 2006.

33. Chang HR, Lian JD, Lo CW, Huang HP and Wang CJ: Aristolochic acid-induced cell cycle G1 arrest in human urothelium SV-HUC-1 cells. Food Chem Toxicol 45: 396-402, 2007.

34. Wu K, Jiang L, Cao J, Yang G, Geng C and Zhong L: Genotoxic effect and nitrative DNA damage in HepG2 cells exposed to aristolochic acid. Mutat Res 630: 97-102, 2007.

35. Simoes ML, Hockley SL, Schwerdtle T, Gamboa da Costa G, Schmeiser HH, Phillips DH and Arlt VM: Gene expression profiles modulated by the human carcinogen aristolochic acid I in human cancer cells and their dependence on TP53. Toxicol Appl Pharmacol 232: 86-98, 2008.

36. Chen T, Guo L, Zhang L, Shi L, Fang H, Sun Y, Fuscoe JC and Mei N: Gene expression profiles distinguish the carcinogenic effects of aristolochic acid in target (Kidney) and non-target (liver) tissues in rats. BMC Bioinformatics 7 (Suppl. 2): S20, 2006.

37. Cheng WY, Hsiang CY, Bau DT, Chen JC, Shen WS, Li CC, Lo HY, Wu SL, Chiang SY and Ho TY: Microarray analysis of vanillin-regulated gene expression profile in human hepatocarcinoma cells. Pharmacol Res 56: 474-482, 2007. 
38. Smyth GK: Limma: linear models for microarray data. In: Bioinformatics and computational biology solutions using $\mathrm{R}$ and bioconductor. Gentleman R, Carey V, Dudoit S, Irizarry R and Huber W (eds). New York, pp397-420, 2005.

39. Montaner D, Tarraga J, Huerta-Cepas J, Burguet J, Vaquerizas JM, Conde L, Minguez P, Vera J, Mukherjee S, Valls J, Pujana MA, Alloza E, Herrero J, Al-Shahrour F and Dopazo J: Next station in microarray data analysis: GEPAS. Nucleic Acids Res 34: W486-W491, 2006.

40. Lebeau C, Arlt VM, Schmeiser HH, Boom A, Verroust PJ, Devuyst $\mathrm{O}$ and Beauwens R: Aristolochic acid impedes endocytosis and induces DNA adducts in proximal tubule cells. Kidney Int 60: 1332-1342, 2001.

41. Liebermann DA and Hoffman B: Gadd45 in stress signaling. J Mol Signal 3: 15, 2008.

42. Cretu A, Sha X, Tront J, Hoffman B and Liebermann DA: Stress sensor Gadd45 genes as therapeutic targets in cancer. Cancer Ther 7: 268-276, 2009.

43. Zumbrun SD, Hoffman B and Liebermann DA: Distinct mechanisms are utilized to induce stress sensor gadd $45 \mathrm{~b}$ by different stress stimuli. J Cell Biochem 108: 1220-1231, 2009.

44. Stemmer K, Ellinger-Ziegelbauer H, Ahr HJ and Dietrich DR Carcinogen-specific gene expression profiles in short-term treated Eker and wild-type rats indicative of pathways involved in renal tumorigenesis. Cancer Res 67: 4052-4068, 2007.

45. Cosyns JP, Jadoul M, Squifflet JP, Wese FX and van Ypersele de Strihou C: Urothelial lesions in Chinese-herb nephropathy. Am J Kidney Dis 33: 1011-1017, 1999.

46. Lord GM, Hollstein M, Arlt VM, Roufosse C, Pusey CD, Cook $\mathrm{T}$ and Schmeiser HH: DNA adducts and p53 mutations in a patient with aristolochic acid-associated nephropathy. Am J Kidney Dis 43: e11-17, 2004.

47. Schmeiser HH, Scherf HR and Wiessler M: Activating mutations at codon 61 of the c-Ha-ras gene in thin-tissue sections of tumors induced by aristolochic acid in rats and mice. Cancer Lett 59: 139-143, 1991

48. Lloyd DR and Hanawalt PC: p53-dependent global genomic repair of benzo[a]pyrene-7,8-diol-9,10-epoxide adducts in human cells. Cancer Res 60: 517-521, 2000.

49. Tsai YS, Lee KW, Huang JL, Liu YS, Juo SH, Kuo WR, Chang JG, Lin CS and Jong YJ: Arecoline, a major alkaloid of areca nut, inhibits p53, represses DNA repair, and triggers DNA damage response in human epithelial cells. Toxicology 249: 230-237, 2008

50. Shen S, Lee J, Weinfeld M and Le XC: Attenuation of DNA damage-induced $\mathrm{p} 53$ expression by arsenic: a possible mechanism for arsenic co-carcinogenesis. Mol Carcinog 47: 508-518, 2008.

51. Wood RD: Nucleotide excision repair in mammalian cells. J Biol Chem 272: 23465-23468, 1997.

52. Conforti G, Nardo T, D'Incalci M and Stefanini M: Proneness to UV-induced apoptosis in human fibroblasts defective in transcription coupled repair is associated with the lack of Mdm2 transactivation. Oncogene 19: 2714-2720, 2000.

53. Wood RD, Araujo SJ, Ariza RR, Batty DP, Biggerstaff M, Evans E, Gaillard PH, Gunz D, Koberle B, Kuraoka I, Moggs JG, Sandall JK and Shivji MK: DNA damage recognition and nucleotide excision repair in mammalian cells. Cold Spring Harb Symp Quant Biol 65: 173-182, 2000.
54. Metzger R, Leichman CG, Danenberg KD, Danenberg PV, Lenz HJ, Hayashi K, Groshen S, Salonga D, Cohen H, Laine L, Crookes P, Silberman H, Baranda J, Konda B and Leichman L: ERCC 1 mRNA levels complement thymidylate synthase mRNA levels in predicting response and survival for gastric cancer patients receiving combination cisplatin and fluorouracil chemotherapy. J Clin Oncol 16: 309-316, 1998.

55. Dabholkar M, Vionnet J, Bostick-Bruton F, Yu JJ and Reed E: Messenger RNA levels of XPAC and ERCC1 in ovarian cancer tissue correlate with response to platinum-based chemotherapy. J Clin Invest 94: 703-708, 1994.

56. Lord RV, Brabender J, Gandara D, Alberola V Camps C, Domine M, Cardenal F, Sanchez JM, Gumerlock PH, Taron M, Sanchez JJ, Danenberg KD, Danenberg PV and Rosell R: Low ERCC1 expression correlates with prolonged survival after cisplatin plus gemcitabine chemotherapy in non-small cell lung cancer. Clin Cancer Res 8: 2286-2291, 2002.

57. Langie SA, Knaapen AM, Houben JM, van Kempen FC, de Hoon JP, Gottschalk RW, Godschalk RW and van Schooten FJ: The role of glutathione in the regulation of nucleotide excision repair during oxidative stress. Toxicol Lett 168: 302-309, 2007.

58. Caggana M, Kilgallen J, Conroy JM, Wiencke JK, Kelsey KT, Miike R, Chen P and Wrensch MR: Associations between ERCC2 polymorphisms and gliomas. Cancer Epidemiol Biomarkers Prev 10: 355-360, 2001

59. Cheng L, Sturgis EM, Eicher SA, Spitz MR and Wei Q: Expression of nucleotide excision repair genes and the risk for squamous cell carcinoma of the head and neck. Cancer 94: 393-397, 2002.

60. Wei Q, Wang LE, Sturgis EM and Mao L: Expression of nucleotide excision repair proteins in lymphocytes as a marker of susceptibility to squamous cell carcinomas of the head and neck. Cancer Epidemiol Biomarkers Prev 14: 1961-1966, 2005.

61. Andrew AS, Karagas MR and Hamilton JW: Decreased DNA repair gene expression among individuals exposed to arsenic in United States drinking water. Int J Cancer 104: 263-268, 2003.

62. Mei N, Kunugita N, Hirano T and Kasai H: Acute arseniteinduced 8-hydroxyguanine is associated with inhibition of repair activity in cultured human cells. Biochem Biophys Res Commun 297: 924-930, 2002.

63. Kinoshita A, Wanibuchi H, Wei M, Yunoki T and Fukushima S: Elevation of 8-hydroxydeoxyguanosine and cell proliferation via generation of oxidative stress by organic arsenicals contributes to their carcinogenicity in the rat liver and bladder. Toxicol Appl Pharmacol 221: 295-305, 2007.

64. Ma H, Wang J, Abdel-Rahman SZ, Boor PJ and Khan MF: Oxidative DNA damage and its repair in rat spleen following subchronic exposure to aniline. Toxicol Appl Pharmacol 233: 247-253, 2008

65. Kang KA, Lee JH, Chae S, Zhang R, Piao MJ, Kim HS, You HJ and Hyun JW: Butin decreases oxidative stress-induced 8hydroxy-2'-deoxyguanosine levels via activation of oxoguanine glycosylase 1. Chem Biol Interact 181: 338-342, 2009.

66. Chatterjee A, Mambo E, Osada M, Upadhyay S and Sidransky D: The effect of p53-RNAi and p53 knockout on human 8-oxoguanine DNA glycosylase (hOgg1) activity. FASEB J 20: $112-114,2006$ 